\title{
Synthesis and Anion Binding Properties of Bifunctional Urea Derivative of Calix[4]diquinone
}

\author{
Jung Min Oh, Eun Jin Cho, Byung Ju Ryu, Young Ju Lee, and Kye Chun Nam \\ Department of Chemistry and Institute of Basic Science, Chonnum National Liniversity, Gwangit 500-757, Korea \\ Received lune +2003
}

Key Words : Bifunctional receptor, Calix[4]diquinone, Urea derivative, Anion binding

The simultaneous binding of cationic and anionic guest species by ditopic receptors is a rapidly developing new field for ion pair recognition of environment and biological importance. By taking advantage of calix[4]arene framework, a few neutral bifunctional receptors ${ }^{1-1}$ were developed and showed the enhanced binding constants of hydrophilic anions in the presence of cations in organic media. As a consequence of their upper and lower rim of topologies the calixarenes are attractive host molecules to modify and so create unicue geometries for the multifunctional receptors. The combination of two binding sites, urea for anions and two podand groups for cations, yields receptor that is capable of binding anions and alkali metal cations simultaneously. In addition to ion binding ability, two quinone moieties are introduced for the redox switchable receptors. ${ }^{5-7}$ We report here the synthesis of a new bifunctional receptor calix[4]diquinone $\mathbf{4}$ containing two urea moieties and two podand groups and the simultaneous binding properties of cation and anion guests were studied.

\section{Results and Discussion}

By taking advantage of a selective 1,3-alkylation, dialkylated urea derivative 3 was prepared by the reaction of $p$-tbutylcalix[4]arene $\mathbf{I}$ and 2-[(2-(N'-phenylureido)ethoxy)ethanol $p$-toluenesulfonate 2 in the presence of $\mathrm{K}_{2} \mathrm{CO}_{3}{ }^{8}{ }^{8} \mathrm{n}$ order to introduce the long urea podand chain into calixarene effectively, 2 was prepared separately from the tosylation of $2-\left[\left(2-\left(N^{\prime}-\right.\right.\right.$ phenylureido $)$ ethoxy $\left.)\right]$ ethanol which was then synthesized by the reaction of 2-(2-aminoethoxy)ethanol with phenylisocyanate (Scheme 1). In order to increase the cooperative binding properties, cone conformers of receptor 4 are desired and under the condition applied the high yield cone products were obtained. Bifunctional urea derivative calix[4]diquinone 4 was prepared from the oxidation of 3 with TTFA (thallium trifluoroacetate) in TFA (trifluoroacetic acid).

The 'H NMR spectrum of 3 shows a pair of doublets at $\delta$ 4.39 and 3.39 for the bridged methylene protons, two singlets at $\delta 0.98$ and 1.31 for $t$-butyl protons, a singlet at $\delta$ 8.01 for $\mathrm{OH}$ protons and a singlet and a triplet at $\delta 7.10$ and 6.52 for $\mathrm{N}-\mathrm{H}$ protons, indicating that 3 exists as a cone conformation. The cone conformation was confirmed by the ${ }^{13} \mathrm{C}$ NMR spectrum," The 'H NMR spectrum of bifunctional calix[4]diquinone urea derivative 4 shows a pair of doublets at $\delta 3.21$ and 4.01 for the bridged methylene protons, a singlet at $\delta 1.08$ for $t$-butyl protons, a broad singlet and a triplet at $\delta 6.38$ and 7.88 for $\mathrm{N}-\mathrm{H}$ protons.

The anion binding properties were examined by ' $\mathrm{H}$ NMR titration experiments in $\mathrm{CDCl}_{\text {; }}$. Substantial down field shift of urea $\mathrm{NH}$ signal was observed when tetrabutylammonium acetate, dihydrogen phosphate, hydrogen sulfate, chloride and bromide salts were added, indicating that anion binding is taking place at the urea vicinity. Figure I showed the ' $\mathrm{H}$

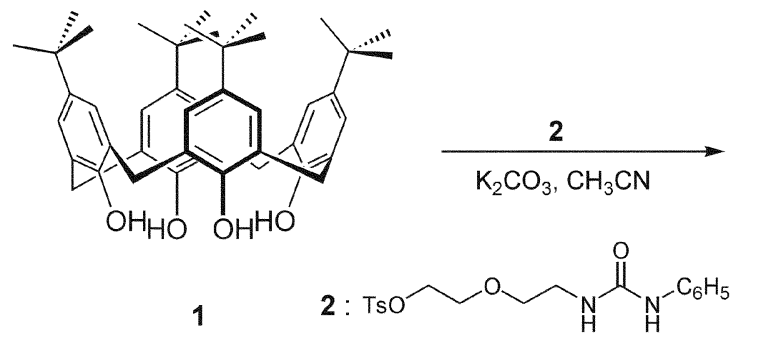

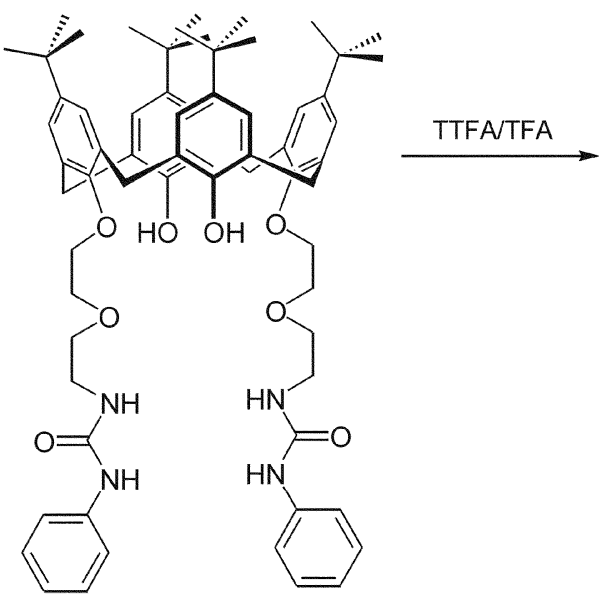

3

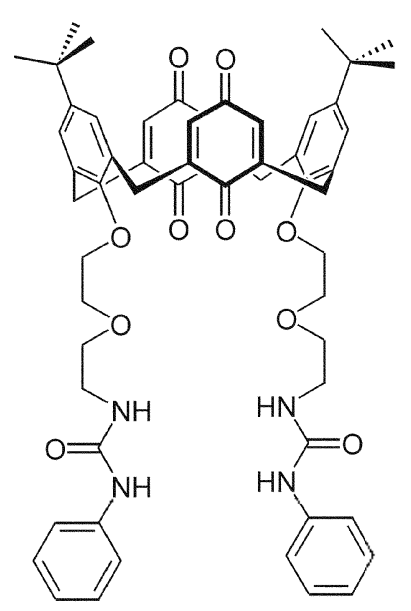

4

Scheme 1. Synthesis of bifunctional receptors. 


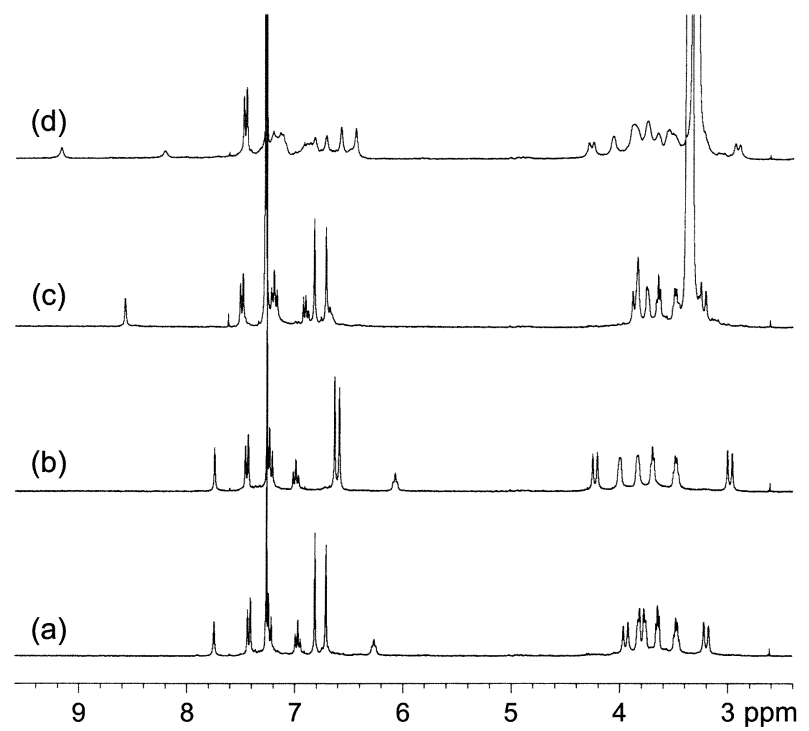

Figure 1. 'H NMR spectra of $\mathbf{4}$ (a) without cation and anion. (b) with 1 equivalent of $\mathrm{NaClO}_{+}$(c) with 5 equivalents of TBACl. (d) with $\mathrm{I}$ equivalen of $\mathrm{NaClO}_{4}$ and 5 equivalents $\mathrm{IBACl}$ in $\mathrm{CICl}_{3}$.

NMR spectra of 4 in the presence sodium and chloride ions. When sodium ions were added, two $\mathrm{N}-\mathrm{H}$ protons signals at $\delta$ 6.38 and 7.88 was not changed much, but a slight upfield shift of two aromatic sinlgets at $\delta 6.80$ and 6.71 and a widening move of a pair of doublets at $\delta 3.21$ and 4.01 for the bridge methylene protons were observed, indicating that sodium ions could be bound at the podand oxygen ether sites" and fixed the conformation of calixarene. Further addition of sodium ions did not change the spectrum. indicating that an 1:1 complex with sodium and 4 could be formed. On the other hand, when chloride ions were added, a large downfield shift of $\mathrm{N}-\mathrm{H}$ protons were observed without changing aromatic signals as shown in spectrum (c) in Figure 1 . In order to investigate the binding enhancement of anions in the presence of alkali metal cations, anion titrations were conducted in the presence of sodium ion. Obviously a further downfield shift of $\mathrm{N}-\mathrm{H}$ proton signals were observed when sodium ions were bound as shown in spectrum (d) in Figure I. Stability constants (Table 1) were calculated from the titration results using EQNMR ${ }^{10}$ for complexation with anions. A significant increase in the strength of anion binding is observed when sodium metal ions are bound simultaneously. Chloride binding strength increase more than 20 fold and bromide binding seven fold in the presence of sodium ion. This positive cooperative binding of the chloride and bromide in the presence of sodium could be attributed through electrostatic effects of the complexed sodium ions. The electrochemical property of 4 was investigated using cyclic voltammetry. The most significant result was observed with $\mathrm{H}_{2} \mathrm{PO}_{4}^{-}$anion. The addition of dihydrogen phosphate anion causes a $27 \mathrm{mV}$ cathodic shift.

In conclusion, bifunctional receptor $\mathbf{4}$ can bind alkali metal cations and halide anions simultaneously with positive cooperativity. This compound has a potential for practical application, and is currently being investigated.
Table 1. Stability constants $\left(K_{u}\right)$ of $\mathbf{4}$ in $\mathrm{CDCl}_{3}$ and cathodic shifts in the presence of anions in D.MF

\begin{tabular}{|c|c|c|c|}
\hline Melat & Anion & $\mathrm{K} / \mathrm{dm}^{3} \mathrm{~mol}^{-1}$ & $\Delta \mathrm{l} \vdots(\mathrm{mV})$ \\
\hline & $\mathrm{H}_{2} \mathrm{PO}_{4} a$ & 2340 & 27 \\
\hline & $\mathrm{HSO}_{4}$ & 1100 & 14 \\
\hline & $\mathrm{CH}_{3} \mathrm{CO}_{2}$ & 890 & 0 \\
\hline & $\mathrm{Cl}$ & 110 & 0 \\
\hline & $\mathrm{Br}$ & 308 & 0 \\
\hline \multirow[t]{5}{*}{$\mathrm{Na}+$} & $\mathrm{H}_{2} \mathrm{PO}_{4}^{-}$ & $-^{h}$ & \\
\hline & $\mathrm{HSO}_{4}^{-}$ & $-^{h}$ & \\
\hline & $\mathrm{CH}_{3} \mathrm{CO}_{2}^{-}$ & $-^{h}$ & \\
\hline & $\mathrm{Cl}^{-}$ & 2200 & \\
\hline & $\mathrm{Br}^{-}$ & 2200 & \\
\hline
\end{tabular}

"Tetrabutylammonium salts. Ferrors estimated to be $<10 \%$. "Duc' to the precipitate. stability constants can not be obtained.

\section{Experimental Section}

5,1 1,17,23-Tetra-tert-butyl-25,27-bis(cyanopropyloxy)26,28-dihydroxycalix $|4|$ arene (1). was prepared by the known procedure. " $\mathrm{mp} \geq 300^{\circ} \mathrm{C}$.

2-|2-( $N^{*}$-Phenylureido)ethoxy|ethanol $p$-toluenesulfonate (2). ]o a solution of $2.0 \mathrm{~g}(8.9 \mathrm{mmol})$ of $2-\left[2-\left(\mathrm{N}^{\prime}-\right.\right.$ phenylureido)ethoxy] thanol in $100 \mathrm{~mL} \mathrm{CH}_{2} \mathrm{Cl}_{2} .5 .1 \mathrm{~g}(26.7$ mmol) of $p$-toluenesulfonyl chloride was added. After the reaction flask was immersed into an ice-water bath, $3.7 \mathrm{~mL}$ of triethylamine was added slowly and stirred for $12 \mathrm{~h}$ at room temperature. Evaporation and extraction with ether provided crude products which was purified by column chromatography (eluent. $\mathrm{CHCl}_{3}$ : acetone $=10: 1$ ) to yield $1.85 \mathrm{~g}(55 \%)$ of 2 . 'H NMR $\left(\mathrm{CDCl}_{3}\right) \delta 7.80\left(\mathrm{~d}, 2 \mathrm{H}_{,} J=6.5\right.$ $\mathrm{Hz}, \mathrm{ArH}), 7.38-7.25(\mathrm{~m}, 7 \mathrm{H}, \mathrm{ArH}$ and NH), 7.05 (t. IH, $J=$ $7.2 \mathrm{~Hz}, \mathrm{ArH}), 6.90$ (br t, IH, NH), 4.24-3.43 (m, 8H, $-\mathrm{CH}_{2}-$ ), $2.45\left(\mathrm{~s}, 3 \mathrm{H},-\mathrm{CH}_{3}\right)$.

$5,11,17,23$ - Tetra-tert-butyl-25,27-bis $\mid 2-\left\{2-\left(\mathrm{N}^{\prime}\right.\right.$-phenylureido)ethoxy ethyl]oxy-26,28-dihydroxycalix [4|arene (3). To a solution of $0.50 \mathrm{~g}(0.77 \mathrm{mmol})$ of 1 and $1.1 \mathrm{~g}$ $\mathrm{K}_{2} \mathrm{CO}_{3}$ in $100 \mathrm{~mL}$ acetonitrile, $0.64 \mathrm{~g}(1.7 \mathrm{mmol})$ of 2 was added. The reaction mixture was refluxed for two days under nitrogen condition. After removing the solvents, the crude products were purified by column chromatography (eluent, $\mathrm{CHCl}_{3}:$ n-hexane : ethyl acetate $\left.-2: \mathrm{I}: 1\right)$ to yield $0.8 \mathrm{~g}$ $(90 \%)$ of 3. 'H NMR (CDCl $\left.1_{3}\right) \delta 8.0 \mathrm{I}(\mathrm{s}, 2 \mathrm{H}, \mathrm{OH}), 7.22-7.18$ and $6.96(\mathrm{~m}, 10 \mathrm{H}, \mathrm{ArH}), 7.14$ and 6.83 (two s, $4 \mathrm{H}, \mathrm{ArH}$ ), $7.10(\mathrm{~s}, 2 \mathrm{H}, \mathrm{NH}), 6.52$ (br t, 2H, NH), 4.39 and 3.39 (a pair of d. $\left.8 \mathrm{H}_{.}, J-13.2 \mathrm{~Hz}, \mathrm{ArCH}_{2} \mathrm{Ar}\right), 4.16-3.59\left(\mathrm{~m}, \mathrm{I} 6 \mathrm{H},-\mathrm{CH}_{2}-\right)$. 1.31 and 0.98 (two s, 36H, $\left.\mathrm{C}\left(\mathrm{CH}_{3}\right)_{3}\right) ;{ }^{15} \mathrm{C}$ NMR $\left(\mathrm{CDCl}_{3}\right) \delta$ 156.1 (-NHCONH-), 149.7, 149.14, 147.5, 143.1, 139.6, $132.5,128.8,128.4,125.84,125.79,122.0$ and $118.8(\mathrm{Ar})$, $75.8\left(-\mathrm{OCH}_{2}-\right), 70.1$ and $70.0\left(-\mathrm{CH}_{2} \mathrm{OCH}_{2}-\right), 40.5\left(-\mathrm{CH}_{2} \mathrm{~N}-\right)$, 34.0, 31.64, 31.59, 31.0 and $29.3\left(-\mathrm{C}\left(\mathrm{CH}_{3}\right)\right.$; and $\left.\mathrm{ArCH}_{2} \mathrm{Ar}\right)$. MS (MALDI TOF) $\mathrm{m} / \mathrm{z} 1084.5(\mathrm{M}-\mathrm{Na})$.

5,17-Di-tert-butyl-26,28-bis|2-\{2-(N'-phenylureido)ethoxy ,ethyl|oxy-26,28|4-25,27-diquinone (4). To a solution of $0.5 \mathrm{~g}(0.46 \mathrm{mmol})$ of 3 in $10 \mathrm{~mL}$ trifluoroacetic acid, $0.75 \mathrm{~g}(1.37 \mathrm{mmol})$ of $\mathrm{Tl}\left(\mathrm{CF}_{3} \mathrm{CO}_{2}\right)_{3}$ was added under 
nitrogen condition. After 24 h stirring the solvents were removed. The crude products were purified by column chromatography (eluent. $\mathrm{CHCl}_{3}$ : acetone $=1: 1$ ) to yield $0.16 \mathrm{~g}(35 \%)$ of $4 .{ }^{1} \mathrm{H} \mathrm{NMR}\left(\mathrm{CDCl}_{3}\right) \delta 7.89$ (s. $\left.2 \mathrm{H}, \mathrm{NH}\right)$. $7.44(\mathrm{~d}, 4 \mathrm{H}, J=7.7 \mathrm{~Hz}, \mathrm{ArH}) .7 .27$ (t. $4 \mathrm{H} . J=6.9 \mathrm{~Hz} . \mathrm{ArH})$. 6.99 (t. $2 \mathrm{H} . J=7.3 \mathrm{~Hz}$. ArH). 6.80 and $6.7 \mathrm{I}$ (two s. $8 \mathrm{H}$. ArH). 6.38 (br t. $2 \mathrm{H}, \mathrm{NH}$ ), $4.0 \mathrm{l}$ and $3.2 \mathrm{l}$ (a pair of d, $8 \mathrm{H} . J=$ $13.0 \mathrm{~Hz} . \mathrm{ArCH}_{2} \mathrm{Ar}$ ). $3.81-3.48$ (m, 16H, $-\mathrm{CH}_{2}-1.08$ (s, $9 \mathrm{H}$. $\left.\mathrm{C}\left(\mathrm{CH}_{3}\right)_{3}\right) ;{ }^{13} \mathrm{C} \mathrm{NMR}\left(\mathrm{CDCl}_{3}\right) \delta 189.2$ and $185.7(-\mathrm{CO}) .156 .1$ (-NHCONH-). 153.2. 148.0, 146.7, 139.9, 132.8, 129.8, $129.3,128.9 .126 .5,125.5,122.2 .118 .9$ and 118.1 (Ar) 73.7 $\left(-\mathrm{OCH}_{2}-\right), 71.0$ and $70.6\left(-\mathrm{CH}_{2} \mathrm{OCH}_{2}-\right), 40.5\left(-\mathrm{CH}_{2} \mathrm{~N}-\right), 34.1$. 31.3 and $29.3\left(-\mathrm{C}\left(\mathrm{CH}_{\hat{3}}\right)_{\hat{3}}\right.$ and $\left(\mathrm{ArCH}_{2} \mathrm{Ar}\right)$. MS (MALDI TOF) $\mathrm{m} / \mathrm{z} 999.5(\mathrm{M}+\mathrm{Na})$

Acknow ledgment. This work was supported by Grant No. R01-2000-00047-0 from the Basic Research Program of the Korea Science \& Engineering Foundation.

\section{References}

1. Scheerder. J.: van Duynhoven. J. P. M: Engberson. J. F. J.: Reinhoudt. D. N. Angew. Chem. Int. Ed. Eng. 1996. 35. 1090

2. Beer. P. D.: Cooper. J. B. Chem. Conmun. 1998. 129.
3. Kang. S. O.: Nam, K. C. Bull. Koman Chem. Soc. 2000, 21 461 .

4. Kang. S. O.: Nam. K. C. Bull. Konew Chent. Soc. 2002. 23. 640 .

5. (a) Reddy, P. A.: Kashap, R. P:- Qatson. W. H.: Gutsche, C. D Israel J. Chem. 1992, 32, 89. (b) Reddy. P. A.: Gutsche, C. D. J. Org. Chem 1993, 58. 3245. (c) Gomez-Kaifer, M.: Reddy. P. A. Gutsche. C. D.: Echegoyen. L. J. Am. Chem. Soc. 1994. 115. 3580 .

6. (a) Beer. P. D.: Chen. Z:: Drew. M. G. B.: Gale. P. A. J. Chen. Soc. Chent Conmt 1994. 2207. (b) Chen. Z.: Gale, P. A.: Beer, P. D. J. Chem. Soc. Faraday Trans. 1994. 90.2207 . (a) Beer, P. D.; Chen. Z: Gale, P. A. Tetrahedron 1994. 50.931.

7. (a) Nam. K. C.: Kang. S. O.: Jeong. H. S.: Teon1. S. Tetrahedron Lett. 1999. 40. 7343, (b) Cho. E. J.: Hwantg. S. S.: Oh. T. M.: Lee. H. K.: Teon. S.: Nam. K. C. Bull. Konean Chent. Soc. 2001. 22. 782. (c) Kang, S. O.: Oh. J. M.; Yang. Y. S.: Chun, J. C.: Jeon, S.: Nam. K. C. Bull Korean Chem. Soc. 2002. 23. 145. (d) Jeong. H S.; Choi. E. M. Kang. S. O.; Nam. K. C.; Jeon. S. J. Electroan. Chem. 2000. 485.154.

8. Collins. E. M.: McKervey. M. A.: Madigant. E.: Moran. M. B. Owens. M.: Ferguson. G.: Harris. S. T. J. Chem. Soc. Perkin Trans. $11991,3137$.

9. Jaime. C.: Mendoza, J. D.; Parados. P; Nieto. P. M. Sanchez. C.J. Org. Chem. 1991, 56. 3372

10. Hynes. M. T. J. Chem. Soc. Dalton Trans. 1993.311.

11. Gutsche. C. D.: Iqbal. M.: Stewart. D. J. Org. Chent 1986. 51. 742 . 